\title{
Osmanlı-Avusturya Rekabetinde Çasarlık İmgesi ve Zitvatorok Antlaşması
}

Öz

Osmanlı Devleti, 16. ve 17. yüzyıllarda dünya üzerindeki süper güçlerden biridir. Bu asırlarda imparatorluk, eski dünya kıtalarında evrensel bir Osmanlı Barışı (Pax Ottomana) tesis etmeye çalışmıştır. Osmanlıların dünya hâkimiyetini sağlamak konusunda en büyük rakibi Habsburglar olmuştur. Biri Madrid, öbürü Viyana merkezli iki kanattan oluşan bu hanedan, Avrupa'da Osmanlı ilerleyişini durdurmayı kendisine misyon edinmişti. Bu durum, o zamana kadar gerçekleşmesi zor ittifakların tesisine imkân vermişti. Bu iki imparatorluğun, birbirine karşıtlı̆̆1 sadece siyasi, dini ve askeri boyutta değildi. Her iki devlet de kendisini Roma mirasının temsilcisi olarak görmekteydi. Habsburg hükümdarları, Kutsal Roma İmparatoru sıfatıyla bu mirasa sahip çıkmaya çalışmışlardır. Osmanlılar, Roma'nın son başkenti İstanbul'u kendi merkezleri yapmışlar ve Roma coğrafyasının önemli bir kısmını ele geçirmişlerdi. Bu durum her iki devletin de Kayzer, (Çaşar) gibi Roma'daki Sezar ve İmparatora dek unvanların kullanılmasını sağlamıştı. Osmanlı ile Habsburg arasındaki rekabet 16. yüzyılda başlamış ve bu rekabet içerisinde, diplomatik unvanların kullanımı çok büyük önem kazanmıştır. Osmanlıların Macar Krallığg’nı 1526 Mohaç Meydan Muharebesinde yenmesiyle başlayan bu sınır komşuluğu ve rekabet 20. yüzyıla kadar sürmüştür. Buna karşın bu rekabet içerisinde diplomatik dengeyi anlayabilmek için en dikkat çeken antlaşmalar 1533'deki İstanbul Antlaşması ve 1606'daki Zitvatorok'tur. Bu iki antlaşma pek çok kez ele alınmış ancak antlaşmaların imzalandığı sırada devletlerin içinde bulunduğu siyasi konjonktür çoğu kez eksik ve yanlış yorumlanmıştır. Çalışmamızda bu iki antlaşmaya yeni bir yaklaşım getirilerek ilgili metinler yeniden bir değerlendirmeye tabii tutulacaktır.

Anahtar Kelimeler: Osmanlı İmparatorluğu, Avusturya, Habsburglar, Çar, Zitvatorok Antlaşması.

\section{The Image of the Kaiser in the Ottoman-Austrian Rivalry and the Treaty of Zsitvatorok}

\begin{abstract}
The Ottoman State was one of the super powers of the world in the 16th and 17th centuries. In these centuries, the empire tried to establish a universal Ottoman Peace (Pax Ottomana) in the old world continents. The biggest rival of the Ottomans for establishing world domination was the Habsburgs. Consisting of two wings, one based in Madrid and the other in Vienna, This dynasty was characterized by its mission to stop the Ottoman advance in Europe. This situation allowed the establishment of alliances that had been difficult to achieve until that time. The opposition of these two empire was not merely political, religious, and military. Both states saw themselves as representatives of the Roman heritage. The Habsburg rulers, in their title as the Holy Roman Emperor, tried to protect this heritage. The Ottomans made Istanbul their administrative center which was the last capital of Roman Empire and captured a significant part of the Roman Geography. This situation enabled both states to use those titles as Kaiser, (Çaşar), Caesar and Emperor of Rome. The rivalry between the Ottomans and the Habsburgs started in the 16th century and the use of diplomatic titles gained great importance in this rivalry. This border neighborhood and the rivalry, which began with the defeat of the Hungarian Kingdom by the Ottomans in the Battle of Mohacs in 1526, continued until the 20th century. In order to comprehend the diplomatic balance in this competition, the most notable treaties are Istanbul Treaty of 1533 and the Zsitvatorok of 1606. These two treaties have been discussed many times, but the political conjuncture of the states at the time of signing of the treatises has often been misunderstood and misinterpreted. In our paper, a new approach to these two treatises will be proposed and the texts in question will be re-evaluated.
\end{abstract}

Keywords: Ottoman Emrpire, Austria, Habsburgs, Tsar, Treaty of Zsitvatorok. 


\section{Giriş}

Roma İmparatorluğu, dünya tarihinin gördügü en uzun ömürlü ve en büyük devletlerinden biridir. Bu imparatorluk Akdeniz dünyasında ve hatta bu coğrafyaya komşu her ülke üzerinde iz bırakmıştır. Roma İmparatorluğu'nun yıkılması tarihteki en büyük siyasal boşluklardan birinin doğmasına neden olmuştu. İmparatorluk coğrafyasının her yerinde görülen yağmalar, isyanlar, istilalar Roma'nın yıkılışının Akdeniz dünyası için ne kadar dramatik sonuçlar doğurduğunu açıkça ortaya koymaktadır. Roma sisteminin tamamen adil olduğunu ve toplumsal sınıfların tamamına huzur getirdiği iddia etmek mümkün değildir ancak bu büyük imparatorluğunun yıkılması ile oluşan kaos ortamı insanlık tarihinin en dramatik siyasal krizlerinden birini meydana getirmiş ve Akdeniz coğrafyasının her yanında isyan, istila, savaş ve göç gibi sorunlar yaşanmıştı (Gibbons, 2019, p. 531-536). Roma'nın yıkılmasıyla oluşan bu boşluğu doldurma gayesi ve Roma'nın mirasını sahiplenme iddiası sadece Batı dünyasının değil, aynı zamanda Doğu dünyasının da bir iddiasıdır.

$\mathrm{Bu}$ iddiayı gerçekleştirmek amacıyla kendilerini zaten Roma’nın devamı olarak gören Bizanslılar; Franklar, Lombardlar ve Germenler ile mücadele vermişlerdi. Ancak Frank kralı Büyük Şarlman'ın800'de Aachen'de Papa III. Leo'nun elinden taç giymesiyle, bu mücadele Bizans ve Germenler arasında yasal bir iddiaya dönüşmüștü. Bizans ile Kutsal Roma Germen İmparatorluğu arasında hem mezhebi hem de siyasi bazlı mücadele, II. ve III. Haçlı Seferi sırasında net biçimde gözlemlenmişti. Alman İmparatoru Friedrich Barborassa'nın sefer güzergâhında büyük sıkıntılar çekerek ölmesi, aslında Bizans'ın gerçek Roma'nın hâlâ kendileri olduğunu iddiasının devam ettiğinin tezahürüydü ve Almanlar bu gerçeği bedel ödeyerek öğrenmişlerdi (Runciman, 1998, s. 12-13).

Bizans İmparatorluğu yıkıldıktan sonra onun egemen olduğu coğrafyaya büyük ölçüde hâkim olan Osmanlı İmparatorluğu'nun; Roma Imparatorluğu'nun kullandığ1 unvanları kullanması, esasen Müslüman Roma iddiasının bir sonucudur. (İnalc1k 2019, s. 229-233) Fatih Sultan Mehmed'in Kayser-i Rum unvanını kullanması, Roma'daki Pontifex Maximus'un muadili bir uygulama olarak Patrik Gennadios'a vezirlik payesi vermesi buna net bir örnektir. Osmanlı devlet sistem içinde başka birçok uygulama Osmanlı'nın yeni Roma olma iddiasına atıf yapmaktaydi.

Osmanlıların cihanşümul imparatorluk iddiası, Roma emperyal hâkimiyet düşüncesi ile özdeşleştiğinden Osmanlı padişahları, Roma ülkesinin hükümdarllğına ve territoryal hâkimiyet unsurlarına atıf yapmaya özen göstermişlerdi. Bu örneklerden el ilginçlerinden biri "kapı" metaforudur. Romalılar, bütün zaferlerinde güç gösterilerini yansıtmak amacıyla kap1 ve takları kullanmışlardır. Romalılar, kapıları; egemenliklerinin en büyük taşıyıcısı olan yolların sadece bitiş noktası olarak görmemişler, aynı zamanda bu kapıları, egemenlik alameti olarak tasavvur etmişlerdi. Nitekim İmparatorluğun başkentinin kapıları Porta Esquilina, Porta Carmentalis, Porta Catularia, Porta Salaria sadece şehre giriş kapıları değil aynı zamanda imparatorların ihtişamlı zafer törenlerinin yapıldığ1 mekanlardı. Nitekim bu gelenek Bizans İmparatorluğu'nda devam etmişti. Adriyatik kıyısındaki Draç Kıyısı'ndan başlayıp İstanbul'a kadar uzanan Via Egnatia'nın sonunda yer alan Altın Kapı, Bizans'ta devleti, imparatoru ve gücü temsil etmekteydi. Bizans Imparatorları seferden muzaffer şekilde döndükleri takdirde Porta Aurea'dan girebilmekteydiler (Nicolle, 2010, p. 145-148). Bu yolla büyük ölçüde örtüşen bir istikamete sahip olan Balkanlar'daki Sol Kol'u kullanan ve seferden İstanbul'a dönen Osmanlı padişahlarının da Edirnekapı'dan törensel şekilde şehre girmesi adettendi. (Heywood, 1999, p. 138-140) Osmanlı İmparatorluğu'nda da kapı devleti temsil ettiğinden dolayı; imparatorluk kurumlarının kapıları devasa yapılıyor ve devlet birimlerin kendileri dahi kapi ismiyle anıliyordu. Osmanlı sadaretini tesmiye eden Bâb-1 Âli dünyaca meşhurdu. Topkapı Sarayı ve Padişahlık Bâb-1 Hümayun ile, Defterdarlık ise Bâb-1 Defteri ile anilmaktaydi. 
Osmanlı ile Roma arasında kapı imgesi üzerinden oluşan benzerliği Cancellarius (Hollond, 1945, p. 17-30) ve Kapicılar Kethüdasina buradan da Kayzer-İmparator imgesine bağlamak mümkündür. Roma İmparatorlarının, hem sekreterleri hem kapı koruyucuları olan Cancellarius, batıdaki devlet geleneğinde hem başbakan hem adalet bakanı hem ekonomi sorumlusu hem de rektör makamının karşıllğında kullanılan Şansölye'nin Roma'daki orijinal versiyonudur. Şansölyelerin görevlerinin ifası bakımından Roma'daki orijinal vazifeye en yakın yetkili Osmanlı'daki Kapicılar kethüdası olup, kethüdâ-i bevvâbîn-i şehriyârî (Özcan, 2001, s. 345-347), kap1 muhafazasından mesul olmakla beraber padişahın özel kalemi veyahut sekreteri gibi çalışmakta ve sadaretle koordinasyonu sağlamaktaydı ki Cancellariusun da tam olarak vazifesi buydu.

Bu bağlamda Osmanlı İmparatorluğu en az batılı devletler kadar Roma İmparatorluk geleneklerine hâkim bir devletti ve bu emperyal birikimi Türk-İslam devlet anlayışı içerisinde mezc ederek çok güçlü bir kurumsal yapı oluşturmuştu. Bu bağlamda Osmanlılar Kayzer ve Sezar tabirinin ne anlama geldiğini hem bizzat kullanarak hem de bu sıfatın kültürel öğelerine kendi devlet mekanizmalarında yer vererek cihanşümul bir iddiayı benimsemişlerdi.

\section{Kanunî Sultan Süleyman ve İstanbul Antlaşması}

Fatih Sultan Mehmed'in İstanbul'u fethi, batı dünyası içinde yaklaşık 650 yıldan beri devam eden bir tartışmanın sonunu getirmişti. Bizans, Roma'nın doğal mirasçısı olduğundan hatta kendisini yıkıldığı güne kadar hep Roma İmparatorluğu olarak tesmiye ettiğinden hükümdarlarının imparator, çar, sezar, kayzer vb. unvanları kullanması tabiiydi. Hatta Diocletianus'un reformlarından sonra, bir dönem için dörtlü yönetime geçildiğinden Caesar (Sezar) unvanı yönetimdeki genç hükümdarlar için kullanan bir tabire dönüşmüştü. Roma İmparatorluğu ikiye ayrıldıktan sonra da bu unvan zaman zaman kullanılmaya devam etmiş ancak Bizans'in kendi doğal devlet yapısını tesis etmesiyle Agustui (büyük imparator) ile Caesarlık yeniden birleşmişti.

Papa III. Leo'nun 800 y1lının Noel'inde Karolenj hükümdarı Şarlman'a (Charlamagne) San Pietro Kilisesinde taç giydirmesi, gerçek kayzerin kim olduğu sorununu ortaya çıkarmıştı. Kuşkusuz, bu sırada Bizans tahtında bir İmparatoriçe İrene'nin bulunması ve bir kadının Romalıların hükümdarı olup olamayacağı sorunsalını beraberinde getirdiğinden taç giyme töreni sırasında Şarlman'ın en azından eli şeklen rahatlamıştı. Karolenj İmparatorluğu'nun Roma veya Roma'nın devamı olmadığı tarihsel bir gerçekti ve Voltaire'in; Essai sur l'bistoiregénérale et sur lesmoeurs et l'espritdesnations isimli uzun makalesinde dediği üzere bu devlet; ne kutsal ne Romalı ne de bir imparatorluktu. Ancak Roma Kilisesi, kendisini hem daha iyi koruyacak hem de sözünü daha iyi dinleyecek bir kayzer arayışındaydı. Şarlman tam da Papa III. Leo'nun isteğine uygun bir imparator adayıdı. Dolayısıyla Hiristiyan dünyanin ve Romalıların imparatoru olmasinda siyaseten bir beis yoktu (Di Girolamo, 2017, p. 175-176). Ancak Bizans'1n tanımadığ1 bir imparatorun gerçek anlamda imparator olmadığı bilindiğinden Şarlman'ın Bizans İmparatoriçesi İrene'e evlilik teklifinde bulunması hem imparatorluk meselesini hem de Bizans'ı karıştırmıs, teklifi kabul eden İrene gösterilen tepki neticesinde tahtını Nikeferos'a kaybetmişti (Gregory 2008, p. 197-198).

Şarlman'ın tahtta çıkmasıyla başlayan, Bizans zayıfladıkça fiili gücün hukukî güce üstünlük sağladığı Germen-Bizans çatışması, Fatih'in İstanbul'u fethiyle sona ermişti veya azından erdiği sanılıyordu. Roma'nın hakiki devamı olan devlet, Türkler tarafından ortadan kaldırılmıştı ve artık III. Friedrich Hiristiyan dünyasındaki tek Roma İmparatoruydu. Ancak Fatih'in, Kayzer-i Rum unvanını benimsemesi, Friedrich'in yeryüzünde tek Roma Imparatorunun kendisi olmadığını işaret etmekteydi. Fatih'in Roma'nın iki başkentinden birine hâkim olması diğerini de ele geçirmek için İtalya’ya yönelik seferler düzenlemesi onun bu unvanın hakkını vermek adına çabasını açıça ortaya koymaktaydi. (Turan, 2000, s. 39-40). 
Osmanlılar, Fatih Sultan Mehmed'den sonra da bu unvanı kullanmaya devam etmişlerdi. Kanuni Sultan Süleyman'ın diplomatik yazışmalarda açıkça kullandığı bu unvan (Demirkent, 2002, 94-96), Osmanlıların batı dünyasının da imparatoru olma iddiasının bir deliliydi. Nitekim Osmanlılar, kendilerine sadece İslam Dünyasının önderi gözüyle bakmamışlar küresel dünya egemenlik iddialarını diplomatik metinlere koymaktan çekinmemişlerdi. Bunun en bilinen örneği ferman elkablarında padişahlar için kullanılan "Fermân-1 cihan muta" (Kütükoğlu, 2013, s. 99) ifadesidir ki burada dünyayı Osmanlı şemsiyesi altında birleştirme iddiası açıkça gözükmektedir.

Ancak Osmanlıların, Romalıların devamcısı olma iddiası, tıpk1 Habsburglar'ın iddiası gibi, temelde imparatorluğun fiili gücüne dayanmaktaydı. Osmanlıların bu savı benimsemeleri aslında batıda da çok görülen unvan üzerinden bir tür hak arayışıydı. İngiltere Krallarının Fransa Kralı, Fransa Krallarının İngiltere Kralı, Leh Krallarının İsveç Kralı, İsveç Krallarının Lehistan Kralı unvanını kullandıkları gibi gerek Osmanlılar gerek Habsburglar Romalıların hükümdarı unvanını bir iddia olarak kullanmaktaydılar. Esasen bu iddiayı tecessüm ettirecek toprak genişliğine ulaşmaktan her iki imparatorluk da uzaktı. Bu bağlamda, iddialarını devam ettirme nedenleri, bu iddiayı gerçekleştirmekten ziyade, dünyaya gözdağı vermek ve kazanımları meşrulaştırmaktı.

Kanuni Sultan Süleyman'ın Macaristan hâkim olması tarihin önemli bir dönüm noktasıdır, ancak zannedilenin aksine Macaristan'ın fethi Osmanlılar'ın en azından başlangıçtaki hedefi değildi. Macaristan ile Osmanlı arasında doğal sınır olan Tuna hattını, Belgrad bozmaktaydı ve buradaki Macar varlığı Osmanlı'nın sınır güvenliğine zarar vermekteydi. II. Layoş’un, selefi II. Ladislas'ın aksine, daha agresif bir diş politika benimsemesi ve Osmanlı'nın doğal sınır kabul ettiği Tuna hattını sürekli tehdit etmekten çekinmemesi, Kanuni'yi Belgrad'a fethetmeye mecbur bırakmıştır. 1521'de Belgrad'ın fethedilmesi, Macarları sakinleştirmek yerine Layoş’u Osmanlı karşıtı büyük bir ittifaka yöneltmiştir. İki ülkenin ilişkilerinin daha da gerilmesiyle 1526'da Osmanlıların kesin zaferi ile neticelenen Mohaç Muharebesi gerçekleşmişti. 1526 seferine çıkılmasında, Fransa Kralı Fransuva'nın elçisi Frangipani'nin, Osmanlı'dan yardım isteğinin etkisi bulunmakla beraber (Yıldız, 2013, s. 65-67) bu seferin ana nedeni, Macar KralıII. Layoş’un Osmanlı karşı ittifakı genişletmeye ve bir Avrupa meselesi haline getirmeye çalışmasıydı.

Osmanlıların Mohaç galibiyeti sonrası uyguladıkları siyaset aslında onların Macaristan'a, hâkim olmak istemediklerini ancak Macaristan kaynaklı bir krize de kesinlikle meydan vermeyeceklerini ortaya koymaktaydı. Bu süreçte tampon devlete dönüşen Macaristan'in beyleri, asilzâde kökenli olmamasına rağmen büyük ölçüde Erdel Prensi Zapolya'yı desteklemekteydiler. İki büyük siyasal güç arasında kalan Zapolya, Osmanlı İmparatorluğu'nun desteğini almayı kendi çıkarları için daha uygun görmüştü.(Rady 2021, p. 115-117). Osmanlıların, Zapolya'y1 desteklemesi üzerine 1528'de Ferdinand, Layoş ile olan akrabalığını bahane ederek Macaristan'a girmiş ve Macar Milli Meclisi tarafindan kral seçilmişti. Zapolya ise ülkenin doğusuna sürülerek saf dışı bırakılmıştı. Zapolya tek başına Arşidük Ferdinand ile başa çıkamayacağını anlayınca, Kanuni Sultan Süleyman'dan yardım istemiş ve Osmanlı orduları 1529'da I. Viyana Seferini gerçekleştirmişlerdi. Bu kuşatma Osmanlılar için bir başarısızlık ifade etse de, Ferdinand'ın Macaristan'da hücum pozisyonundan kendi payitahtını savunma noktasına gelmesi, stratejik bakımından önemlidir. (Yücel, 1987, s. 35-37 ). Viyana kuşatmasından sonra 1532'de Habsburglar'ın tek başına Osmanlı'ya gücü yetmediği anlaşılınca Şarlken bizzat Regensburg'taki İmparatorluk Dieti'ne gelerek, Osmanlı'ya karşı hücum hazırllğı yapsa da Osmanlı karşı taarruzu karşısında Habsburglar sahaya çıkmaya cesaret edemeyerek barışa mecbur kalmışlardı. Şarlken,1532'de Viyana'ya gelmiş ancak Osmanlı ordusunun Güns Kalesi önünde fazlaca vakit kaybetmesi Osmanlılar'ın bir kez daha Viyana üzerine yürümesine engel olmuştu (Gökbilgin, 1970, s. 22-24).

Viyana'nın sürekli tehdit altında kalması 1533 yazında Habsburglar ile Osmanlıları barış yapmaya sevk ettirdi. Ferdinand'ın 1532'de ağabeyi Şarlken'in Viyana’ya geldiği sırada Osmanlı’ya 
karşı nasıl tedbirler aldığıve aklındaki sulh şartlarının ne olduğu bir muammadır. Ama Kanuni’ye karşı bir Haçlı seferi düzenleme söylentilerinin tam aksine Katolik din adamları dahi Şarlken'in Osmanlılarla barış yapmasının faydalı olabileceği kanısındaydı. Osma ve Siguenza Kardinal Psikoposu Don Garcia Loaysa Şarlken'e şu şekilde seslenmişti: “ Majesteleri, Türklerle barış yapılırsa ya da majesteleriyle ve Macaristan kralı ile uzun süreli bir ateşkes antlaşması yapmak istiyorlarsa, bu herkesin iyiliği için yararlı olabilir. Ama bu öyle yapılmalı ki, ilk adımı atmamıza rağmen majestelerinin onurunu ayaklar altına alınmamalı. Ayrıca Yanoş Zapolyo ile bir sulh yapılmasını tavsiye ederim. Ama hiçbir şekilde kral unvanı taşımaması şartıyla (Zinkeisen, 2011, 495-496). Görüldüğü üzere Kutsal Roma İmparatorluğu'nun devlet aklı, Osmanlı ile çatışmak yerine onunla sulh yapmayı çıkarına uygun görüyordu. Bu tercihin iki temel nedeni bulunmaktaydı. Arşidük Ferdinand'ın Osmanlı ile baş edebilecek gücü bulunmamaktaydı. İkinci neden ise, Osmanlı'nın Macaristan seferleri temelde, yayılımdan çok, olası bir tehdidi ortadan kaldırmaya yönelik önlem amaçlı operasyonlardı. Ferdinand'ın bölgedeki Osmanlı meşruiyetini tanıyarak, sulh yapması, Osmanlıların bu tehdit algısından uzaklaşması demekti.

Ferdinand'ın aslında 1532'de gerçekleştirmek istediği ama çıkan anlaşmazlık neticesinde Alman seferine neden olan barış teşebbüsü 1533'te bu kez başarıya ulaştı. Ferdinand, Schepperus'u sulh yapmak üzere İstanbul'a göndermişti ve Avusturya elçisi üst düzey muhatap olarak Sadrazam İbrahim Paşa ile görüşme imkânı bulmuştu. Ancak Macaristan'ın hangi topraklarının Avusturya'da kalacağı, Şarlken'e bağlı çalışan Andre Doria tarafindan işgal edilen Koron'un Osmanlı'ya geri verilip verilmeyeceği gibi konular, müzakereler içinde bir tartışma konusuydu. Bütün bu sorunlar Osmanlı hizmetinde görev yapan usta diplomat Gritti'nin de yardımıyla neticelenmiş ve yazılı olmayan ve padişahın sözüne dayanan bir sulh sağlanmıştı (Zinkeisen, 2011, p. 531-532).

Ferdinand'ın padişaha denk sayılmaması, metin yazılı olmadığından ötürü, ancak dönemin yabancı kaynaklarının aktardığı bilgilerden anlaşılmaktadır. Osmanlı'nın asıl protokol üstünlüğü metnin sözlü olmasında yatmaktadır. Zira padişah bir bakıma adeta lütuf olarak antlaşmayı Avusturyalılara bahşetmiştir. Bu bağlamda, İbrahim Paşa'nın, Ferdinand ile kendini kardeş görmesi yani protokolde kendine denk sayması, Kanuni Sultan Süleyman'ın bir baba figürü olarak bir üst kademede düşünüldüğü kaynaklarda ittifakla kabul görmüştü. Burada Osmanlıların, Avusturya Arşidükü'nün temsilcilerine, bir imparatordan ziyade bir kralın elçisine uygulanan protokolü uyguladığı açıktır.

1533’te Osmanlılar iki Habsburg devletinin arasında net bir ayrım yapmıștır. Ferdinand ile Şarlken'in otoriteleri müzakerelerde net bir şekilde ayrilmış ve Osmanlı sadece Avusturya ile sulh yapmıştı. Şarlken ile sulh yapılmadığı net şekilde ortadır zira Schepperus bu kez Şarlken’in elçisi sıfatıyla 1534'de İstanbul'a gelmiştir. Ancak Şarlken'in elçisi çok kötü bir şekilde ağırlanmış ve kendisi ile sulh yapilmamıştır (Jorga, 2005, p. 350-352). Şarlken ile sulh yapılmamasının nedenleri, Amiral Doria'nın Koron'dan çıkmak istememesi, Almanlar'ın Fransa'ya saldırması ve Akdeniz'de sürekli Osmanlı aleyhine faaliyet gösterilmesidir. Osmanlı’nın Şarlken'inin elçisine çok olumlu yaklaşmadıkları aşikârdır ama Şarlken bu dönemde "kayzer" olarak telakki edilmektedir. Osmanlıların kayzer sıfatından ziyade kabul etmedikleri unvan, Kutsal Kudüs Kralı sıfatıdır ki, Kutsal Roma Germen imparatorlarının, Haçlı seferlerinden beri kullandıkları bu şekli unvan, Osmanlıların, kendi egemenlik sahalarında bulunan bir toprak üzerinde başka bir devletin hak iddia etmelerini onaylamaları mümkün değildir.

Osmanlılar, bu sulhtan sonra 1562'de artık tahttan feragat eden ağabeyinin yerine Kutsal Roma İmparatoru olan Ferdinand ile yeni bir sulh yapmıslardır. Osmanlılar, 1566'dakiZigetvar seferinden sonra, yeni imparator II. Maksimilyan ile 1568'de sulh yapmışlardı. Bu sulh sekiz seneliğine yapılmıştı. 1576'da Sultan III. Murad, ölen Maksimilyan'ın yerine geçen II. Rudolf ile, 1576'da, 1568'teki sulhu yenilemişti. Bu antlaşmalarda, Osmanlılar münhasıran kayzer/çasar 
unvanını kullanmaktan imtina etmişlerdi. Bununla beraber zımmen Çasar anlamına gelen Alman Vilayeti'nin, vech-i İslovin ve Hirvat taifesinin emiri İftihârü'l-ümerâi'l-izâmi'l-Îseviyye, muhtârülküberâi'l-fihâm fî milleti'l-Mesîhiyye unvanlarını Avusturyalı muhatapları için kullanmışlardı. (Anonim, Muahedat, 1297, s. 60-69)

\section{Zitvatorok Antlaşması ve Kayzerlik}

Osmanlı İmparatorluğu ile Avusturya arasındaki rekabet, 16. yüzyılın sonunda bir kez daha savaşa dönüşmüştür. Habsburglar gerek Osmanlıların İran cephesine odaklanması gerekse de Erdel ve Memleketeyn Prenslikleri ile gizli ittifak kurabilmiş olmalarının avantajıyla, Osmanlı İmparatorluğu ile savaşa girişmişlerdi. Savaşın görünürdeki nedeni, başıbozuk Uskoklar’ın sürekli olarak Budin Eyaleti'nin topraklarına saldırması ve buna mukabil Telli Hasan Paşa'nın Avusturya serhaddinde yaptığı faaliyetlerdi. Avusturyalıların, Telli Hasan Paşa'nın hareketlerini Bab-1 Âli nezdinde protesto edip, Macaristan'ın kendilerinde kalan kısmı için ödedikleri vergiyi kesmeleri Osmanlı-Avusturya savaşına giden ilk adımdı. Telli Hasan Paşa'nın, Siyavuş Paşa'nın yerine sadrazamlığa gelen Koca Sinan Paşa ile kavgalı olması ve Sinan Paşa'nın intikam duygusu ile Telli Hasan Paşa'ya yeterli desteği sağlamaması, Hasan Paşa'nın Siska kalesi civarında kıstırllip suyu geçmeye çalışırken şehit olması savaşa neden olmuştu (Peçevi, 1968, s. 342-345).

13 Y1l Savaşları olarak da bilinen, 1593-1606 Osmanl1-Avusturya Savaşları, Osmanlı ordusunun çektiği sıkıntılar ve eski parlak devirlerden uzak bir askeri dönem olarak düşünülmektedir. Bu düşünceye istinaden Zitvatorok Antlaşması'nın bir başarısızlık metni olduğu ve Osmanlı İmparatorluğu'nun askerî ve siyasî açıdan prestij kaybettiği düşünülmektedir. Öncelikle 13 Yıl Savaşları Osmanlı İmparatorluğu için başarısız bir dönem değildir. Telli Hasan Paşa gibi yetenekli bir devlet adamının şehit olmasıyla başlayan Osmanlı'ya vasal oldukları hâlde Erdel Krallığı, Eflak ve Boğdan Prenslikleri'nin Avusturya yanında Osmanlı'ya hücum etmesi ile büyük bir krize dönüşen, Estergon gibi kritik öneme sahip bir kalenin düşmesi ile devam eden savaşın sonunda Osmanlılar, Avusturya’ya karşı büyük bir üstünlük ve moral ile ayrılmışlardı.

Savaşa iştahla başlayan taraf Avusturya olmasına rağmen,1606'da Budin'e gelerek sulh istemeye mecbur kalan taraf yine Avusturya olmuştu. Savaşın başında kaybedilen Estergon, 1605'te Lala Mehmed Paşa tarafindan fethedilmişti. (Güvenç, 1985, 149-154).13 yıllık savaş sırasında bir eyalet merkezi olan ve Kuzey Macaristan'ın kontrolünü sağlayan Eğri (Eger, Erlau) ve müstahkem bir kale olup Transdanubya bölgesini kontrol eden Kanije (Nagykanizsa) kaleleri fethedilmiştir. Savaşın başındaki moral bozukluğu ve yaşanan sıkıntılara rağmen Osmanlılar bu büyük krizden çok başarılı bir şekilde sıyrılmışlar ve savaşın sonunda hücum inisiyatifini ele geçirmişlerdi. Bir başka deyişle savaş sona erip taraflar Zitvatorok'ta masaya oturdukları sırada, hem hücum inisiyatifi hem moral üstünlügü hem de toprak kazanımı bakımından Osmanlılar Avusturya'ya karşı üstün konumdaydılar. Nitekim antlaşmanın Avusturya bakımından elverişsiz şartlar içermesi, metnin imzalanması hususunda, İmparator II. Rudolf ile yeğeni Mattias arasında ihtilaf doğmasina neden olmuştu (Karl, 2018, p. 142).

Zitvatorok Antlaşması, H.1015/M.1606 tarihinde imzalanmış olup Osmanlı tarihlerinde Jidva Sulhu olarak bilinmektedir. 20 yıllığına imzalanmış olan bu barış antlaşması 12 maddeden ibarettir. (Muahedat, 1297, p. 69-77). Antlaşma şartlarını Osmanlı Devleti adına Budin Beylerbeyi Ali Paşa’nın kethüdası Ahmed Ağa müzakere etmiştir (Katip Çelebi, 2016, s. 479-481).

Antlaşmanın en dikkat çeken iki noktası vardır. Bunlardan birincisi Osmanlılar'ın 1533'ten beri aldıkları yıllık verginin artık toplanmamasıdır. Hakikat, Osmanlılar'ın daha önce Yukar1 Macaristan'ın Avusturya'ya bırakılmaması karşılı̆̆ında Osmanlı İmparatorluğu'na vermeyi taahhüt ettiği vergiyle alakalı antlaşmada bir madde bulunmamaktaydı. Bu verginin verilmemesi için Arşidük Mathhias'ın özel çaba sarf ettiği bilinmektedir (Popp, 2013, p. 472-474). Ancak burada gözden kaçırılmaması gereken husus, Yukarı Macaristan olarak bilinen toprakların önemli bir kısmının bu antlaşma ile Osmanlı hâkimiyetine girmiş olmasıdır. Yukarı Macaristan bölgesinin en 
önemli şehri Eğri'dir ve antlaşma sonrası Orta Macar denilen ince bir şerit dişında Macaristan topraklarında Avusturya hâkimiyeti artık sona ermiştir. Bir bakıma Eğri'nin fethi ve bu fethin antlaşma ile tanınmasıyla verginin toplanma nedeni de ortadan kalkmıştır.

Zitvatorok Antlaşması'nın ikinci önemli noktası İmparator-Çasar Kayzer meselesidir ki Osmanlılar antlaşmanın ikinci maddesinde açıkça II. Rudolf için İmparator tabirini kullanmışlardı. Osmanlıların bu tabiri kullanmalarının temel nedeni, artık Alman Imparatorluğu'nun merkezinin Viyana'ya kaymasıydı. Burada ilginç bir durum daha bulunmaktadır. Antlaşmayı Arşidük Mattias imzalamış ve yeğeni ile kavgalı olan İmparator Rudolf metni kerhen kabul etmiştir. Osmanlıların antlaşmanın ikinci maddesinde Rudolfa atıf yapmaları esasen sulhun geçerli olabilmesi için, İmparatorun onayına mebni olması ile doğrudan alakalıdır. 1533'te İstanbul Antlaşması'nda muhatap olarak Ferdinand kabul edildiği, ama Şarlken ile anlaşılamadığı için, padişahın Ferdinad'a protokoldeki üstünlüğünü net biçimde ortayakoyarak metni imzalayan Osmanlılar, bu kez yine Arşidük ile metni imzalamışlar ama kendi asıl muhatapları İmparator II. Rudolf olduğu için onun onayına atıf yapmışlardır. Osmanlılar, Kutsal Roma İmparatorunun Kayzer-İmparator unvanını kullanmasından pek hoşlanmasalar da, bunu gerek zımnen gerek alenen teyit etmişlerdir. Zitvatorok Antlaşması'nda Rudolf için İmparator tabirini açıkça kullanmaları, garip bir şekilde Rudolf u oldu-bittiye getiren yeğeni Mattias'ın razı, kendisinin ise memnun olmadiğı bir antlaşmayı, imzalamaya Rudolfun mecbur bırakılması ile alakalıdır. Osmanlılar, Zitvatorok'ta istedikleri şartta bir sulhu elde etmişler ve imparator unvanının yer aldığı bu maddeye istinaden Rudolfu antlaşmayı imzalamaya mecbur bırakmışlardı. Üstelik bu madde ile Osmanlı Devleti'nin gerçek muhatabının ancak imparator olabileceği bunun dışındaki hiçbir yetkilinin tek başına Osmanlı ile sulh yapamayacağı, kayıt altına alınmaktaydı. Bu bakımdan Zitvatorok, diplomatik bir düşüşü değil zaferin hukuki zemine yansıtılmasını ifade etmekteydi.

\section{Sonuç}

Osmanlı İmparatorluğu ve Habsburglar, 16. ve 17. yüzyllın iki büyük süper gücüdür. Birbiriyle sürekli çatışma hâlinde olan bu iki imparatorluk, Sünnî İslam ve Katolik Hıristiyanlığın bayraktarlığını üstlenmişlerdi. Çok kültürlü ve farklı etnik unsurları bünyelerinde bulunduran yapılarına rağmen, Osmanlı İmparatorluğu temelde bir Türk, Kutsal Roma İmparatorluğu ise bir Alman devletidir. (Stollberg-Rilinger, 2020, p. 21-23) Ancak bütün bu majör farkllliklar ve karşıtlıklarına rağmen her iki devlet de territoryal-emperyal iki devletti ve kökeni Romalılara ve hatta Sasanilere kadar uzanan Eski dünyanın emperyal geleneğini bünyesinde barındırmaktaydılar. $\mathrm{Bu}$ açıdan iki devlet adeta birbirlerinin ters simetriğiydiler.

Kayser-Çasar unvanı, her iki devletin kullandığı birçok unvan gibi kökeni Roma İmparatorluğu'na dayanan bir sıfattır. Osmanlılar Fatih döneminden itibaren bu unvanı kullanmaktan imtina etmemişlerdi. Hatta Pax Ottomana veya Kızıl Elma ülküsünün gereğince, Osmanlılar Rusya gibi rakip devletlerin bu unvanı kullanmasına olumsuz bakmışlardı. Buna mukabil, Kanunî Sultan Süleyman devrinden itibaren, Osmanlılar, Habsburgları kendilerine denk bir kuvvet olarak görmüşler ve Habsburg hiyerarşisinin en üstünde bulunan ismin İmparator unvanının bir karşılığı olarak Çasar unvanını kullanmasını tabii karşılamışlardı. İki devletin 16. yüzyılın başlayıp 20. yüzyıla kadar uzanan uzun siyasi diplomatik münasebetleri boyunca her iki devlet de, muhatabını imparatorluk olarak görmüş ve bu en üst düzey unvan üzerinden ilişki kurmuşlardi.

Osmanlı tarih yazıcıllğındaki en kalıp ifadelerden biri de Zitvatorok Antlaşması'nın, Osmanlı Devleti'nin askerî ve siyasal güç kaybına uğramasının bir tezahürü olduğuna dair yorumlardır. Osmanlılar, eskiden kuvvetli oldukları için, rakipleri Avusturyalıların Çasar-Çar unvanını kullanmasına izin vermezlerken, imparatorluğun zayıflaması ile beraber bu durumu Zitvatorok'ta kabullendiklerine yönelik ifade defalarca kez tekrarlanmıştır. Hâlbuki bu yorum, olaya sadece Osmanlı askeri tarihinden bir bakış açısıdır, üstelik zorlama bir yorumdur. Öncelikle 
Zitvatorok, Osmanlıların galibiyetle bitirdikleri bir savaşı noktalayan bir sulh muahedesidir ve Osmanlı kazanımları Avusturyalılarca da teyit edilmiştir. Ancak bundan da önemlisi Habsburgların kendi devlet mekanizmalarında hiyerarşik düzenin göz ardı edilmesidir. Bu durum antlaşmanın çok yanlış bir şekilde yorumlanmasına neden olmuştur. Zira 1533 yılında imzalanan İstanbul Antlaşması'nda Avusturya Arşidükü Ferdinand'ın, Osmanlı Sadrazamı Makbul İbrahim Paşa'ya denk sayılması, Habsburg devlet protokolünün bir neticesidir. Bu bağlamda Avusturya Arşidükü Ferdinand, o sırada bir imparator değil, İmparator Şarlken'in kardeşidir. Şarlken ise, bu dönemde Madrid sarayında yaşamakta, dolayısıyla kendisinin Osmanlı ile karadan bir askerî-siyasi iletişimi bulunmamaktadır. Bu bağlamda Kanunî Sultan Süleyman'ın kendisi ile Arşidük Ferdinand'ı denk saymayarak, Ferdinand'1 sadrazamına denk görmesi, bir üstünlük değil, diplomatik hiyerarşinin doğal bir sonucudur.

Şarlken'in 1556'da tahttan feragat etmesiyle Kutsal Roma İmparatorluğu'nun başına Ferdinand'ın geçmesi, iki kanatlı bu imparatorlukta rollerin değişmesine neden olmuştu. Şarlken'in iktidarında Madrid'de oturan monark "İmparator veya "Kayzer" iken, Viyana'daki hükümdar "kral" veya onun dengi bir unvan olan "Arşidük" sıfatını taşımaktaydı. 1556'dan itibaren Viyana'daki hükümdarlar artı imparator, İspanya'dakiler ise kral unvanını kullanmışlardı. $\mathrm{Bu}$ bağlamda Zitvatorok'ta yapılan işlem aslında imparatorun kendini padişaha denk kabul ettirmesi değil, 1556'daki değişikliğe paralel biçimde kendisinin imparator olarak tanımlanması ile alakalıdır. Zitvatorok'ta Osmanlılar diplomatik üstünlüklerini kaybetmemişler, kendilerine eşit kabul ettikleri imparatorun artık Madrid'de değil, Viyana'da oturduğunu kabul etmişlerdi. Rudolf un bu antlaşmayı imzalamak istememesi ama buna mecbur kalması dahi Zitvatorok'un Osmanlı için olumlu bir antlaşma olduğunu ortaya koymaktadır.

\section{Kaynakça}

Anonim. (1297). Muahedat mecmuası III, İstanbul Ceride-i Askeriyye Matbaası.

İbrahim Peçevi. (1968). Peçevi tarihi, (M. Uraz, Çev.). Neşriyat Yurdu.

Demirkent, I. (2002). Kayser. İçinde İslam Ansiklopedisi (Cilt 25, ss. 94-96). Türkiye Diyanet Vakfi Yayınları.

Di Girolamo. C. (2017). Şarlman’dan bin yılına. İçinde U. Eco (Ed.). Orta Çăg (Cilt I, ss. 173-181), Alfa Yayınları. Yayınları.

Gibbons, E. (2019). Roma Imparatorluğg'nun gerileyiş ve çöküss taribi, (A. Baltacigil, Çev.). İndie

Gökbilgin, T. (1970). Kanuni Sultan Süleyman'ın Macaristan ve Avrupa siyasetinin sebep ve smilleri, geçirdiği safhalar, İçinde Kanuni Armağam (ss. 5-39). Türk Tarih Kurumu.

Gregory, E. T. (2008). Bizans taribi, Yap1 Kredi Yayınları.

Güvenç, L. (1985). Osmanl devri, Osmanl-Avusturya Harbi (1593-1606). Genelkurmay Askeri Tarih ve Stratejik Etüt Başkanlığ1 Yayınları.

Heywood, C. (1999). Osmanlı döneminde Via Egnatia: 17. yüzyıl sonu ve 18. yüzyıl başında Sol Yol'daki menzilhaneler, İçinde Elizabeth Zachariadou (Ed.) Sol Kol, (ss. 138-160). Tarih Vakfi Yurt Yayınları.

Hollond, H. A. (1945). Some early Chacellors. The Cambridge Law Journal, 9(1), 17-30.

İnalc1k, H. (2019). Devlet-i Aliyye Osmanh Imparatorluğu üzerine araștormalar IV, Türkiye İş Bankası Kültür Yayınları.

Jorga, N. (2005). Osmanl Imparatorluğu taribi, II, Yeditepe Yayınevi.

Karl, B. (2018). Objects of prestige and spoils of war, In Z. Biedermann, A. Gerritsen \& G. Riello (Eds), Global Gifts: The Material Culture of Diplomacy in Early Modern Eurasia (pp. 119-170). Cambridge University. 
Gürcan, F. (2021). Osmanlı-Avusturya rekabetinde çasarlık imgesi ve Zitvatorok Antlaşması, Mavi Atlas, 9(2), 182-190

Katip Çelebi (2016). Fęleke I, (Z. Aybicin, Haz.). Çamlıca Basım Yayın.

Kütükoğlu, M. (2013). Osmanl belgelerinin dili, Türk Tarih Kurumu.

Nicolle, D. (2010). Konstantinopolis'in düsüş̈̈ Osmanlılarn Bizans' fethi. Kitap Yayınevi

Özcan, A. (2001). Kapıcı. İçinde İslam Ansiklopedisi (Cilt 24 ss. 345-347). Türkiye Diyanet Vakfi Yayınları.

Popp, S. (2013). Zitvatorok Antlaşması. İçinde İslam Ansiklopedisi (Cilt 44, ss. 372-374). Türkiye Diyanet Vakfı Yayınları.

Rady, M. (2021). Habsburglar. Kronik Yayınları.

Runciman, S. (1998). Haçl Seferleri taribi III. Türk Tarih Kurumu.

Stollberg-Rilinger, B. (2000). Kutsal Roma Imparatorluğu. (M. Tuncay, Çev.). Vakıfbank Kültür Yayınları.

Turan, O. (2000). Türk cihan bâkimiyeti mefkuresi. Boğaziçi Yayınları.

Yücel, Yaşar. (1987). Mubteşem Türk Kanuni ile 46 yll, Atatürk Kültür, Dil ve Tarih Yüksek Kurumu

Yildız, Y.(2013). Osmanl-Habsburg iliskilleri. Türk Tarih Kurumu.

Zinkeisen, W. J. (2011). Osmanl Imparatorluğu taribi, II, Yeditepe Yayınlar1. 